\title{
Knowledge and practice of primary school teachers about first aid management of selected minor injuries among children
}

$\pi$
0
0
0
5
0
$\frac{\pi}{4}$

\section{Shobha Masih, Rajesh Kumar Sharma', Atul Kumar}

Departments of Community Health Nursing and ${ }^{1}$ Medical Surgical Nursing, Himalayan College of Nursing, Dehradun, Uttarakhand, India

Address for the Correspondence: Asst. Prof. Rajesh Kumar Sharma, Department of Medical Surgical Nursing, Himalayan College of Nursing, Swami Rama Himalayan University, Swami Ram Nagar,

Dehradun - 248 140,

Uttarakhand, India.

E-mail: rajeshsharma.hcn@ gmail.com

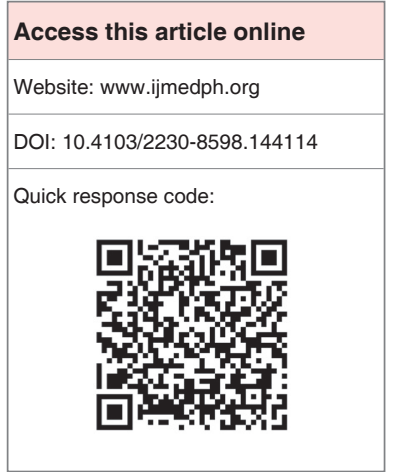

Introduction: Children spend most of the time in school where they are exposed to various types of minor injuries, which influence their present and future state of health. First aid is the treatment of any injury or illness before availability of professional medical aid. Teacher is the key person who can attend the children for minor injuries in school through complete knowledge regarding first aid management. This study was done among primary school teachers to evaluate the effectiveness of teaching program on knowledge and practice regarding first aid management of selected minor injuries in children. Materials and Methods: A Quasi-experimental study with one group pre- and post-test research design was conducted among the primary school teachers of Dehradun district of Uttarakhand. Fifty primary school teachers were selected by nonprobability convenient sampling. Data were collected by knowledge questionnaire (maximum possible score 42) and self-reporting checklist (maximum possible score 23). Result: Majority (94\%) of the teachers were female. Paired sample $t$-test revealed that the mean posttest knowledge score regarding first aid management of selected minor injuries was significantly higher (34.76 \pm 4.35$)$ than that of mean pretest knowledge score $(27.32 \pm 5.73)(P<0.005)$; mean posttest practice score was significantly higher $(18.52 \pm 2.63)$ then mean pretest practice score $(14.52 \pm 2.39)(P<0.005)$. There was a significant positive correlation between knowledge score and practice score of participants $(r=0.9$; $P<0.001)$. Conclusion: This concludes that the training program was effective in significant improvement of knowledge and practice score regarding first aid management of selected minor injuries among study participants. Findings stress the need for such training programs, which in turn may enhance the overall health standard of the children.

Key words: Educational package of first aid, first aid management, knowledge and practices of teachers, primary school teachers, selected minor injuries

\section{INTRODUCTION}

First aid is the treatment of any injury or sudden illness before professional medical help can be provided. The aim is to prevent the condition getting worse, ensuring fast recovery and preserving the precious human life. Most injuries are minor and can be treated without medical attention such as bruises, minor fractures, sprains, and strain. The knowledge of first aid, when properly applied, can bridge the gap between temporary or permanent injury, rapid recovery, or long-term disability. ${ }^{[1]}$

Children spend most of the time in school under the direct supervision of teachers. They are also exposed to various types of epidemiological factors in the school, which influence their present and future state of health. ${ }^{[2]}$ Hence, first aid should be known by school teachers to meet the urgent needs of these school children during minor injuries. Teacher is the key person in school who attend such type of victims and always in a position to save the life. Healthy safe environment is very important to avoid these hazards beside qualified teachers who can detect any health problem and can give first aid for commonly occurring emergencies in schools. ${ }^{[3]}$

During my clinical experience posting in the community, I have treated many school children for minor injuries in our health center and during the visit to many primary schools for health checkup. 
The school nurse or any other health worker would not always be at the school when first aid treatment is needed, and also when children have accidents away from the school; consequently it is desirable that teachers and other staff should be properly taught to take care of the minor accidents that occur in and around the school. ${ }^{[4]}$ The responsibility of school teacher is also to provide a first aid care to children at school campus. Hence, they should be trained adequately to deliver health care to injured children in emergency. The primary purpose of the study was to make school teachers more competent in proving first aid care for minor injured children in primary school through structured educational package. This may apply their knowledge and practice regarding the first aid management of selected minor injuries to encounter the children at primary school, which would further help in reducing the complications and advancement of the problem. Indirectly, it would also help in reducing absenteeism rate of primary school children due to minor injuries.

\section{MATERIALS AND METHODS}

A Quasi-experimental study with one group pre- and post-test research design was conducted among the primary school teachers of Dehradun district of Uttarakhand. Fifty primary school teachers were selected by nonprobability convenient sampling was applied for selection of samplem [Table 1].

A structured knowledge questionnaire was developed with the following components:

1. Baseline demographic data.

2. Knowledge questionnaire regarding first aid Management of minor injuries among primary school children and

3. Self-reporting practice checklist after validation and reliability of tools.

After obtaining the permission from the Institutional Ethical Committee and District Education Officer and informed consent was obtained from all study subjects, data were collected by using the Knowledge Questionnaire and self-reporting practice checklist. A structured educational package was administered to improve the knowledge and practice of the primary schools teachers.

\section{RESULTS}

Table 2 shows that majority (94\%) of the school teachers were female, an equal distribution (50\%) was seen in age group upto 40 years and above 40 myears. Sixty parcent samples were married and $73.33 \%$ were having more than one child. Majority $(84 \%)$ school teachers were having $0-15$ years of teaching experience. Most of the school teachers $(72 \%)$ had previous experience of handling injured children in schools. Majority of primary school teachers did not attend $(86 \%)$ any specific seminar or workshop related to first aid management of minor injuries, but majority (74\%) of school teachers had appropriate information about first aid management through literature like health newspapers,

\begin{tabular}{|c|c|}
\hline Name of primary school & Number of teachers \\
\hline $\begin{array}{l}\text { Rajakiya Prathamik Vidhiyala Keshpuri } \\
\text { Basti, Doiwala, Block Dehradun }\end{array}$ & 6 \\
\hline $\begin{array}{l}\text { Sweta Public School Premnagar, Doiwala, } \\
\text { Block Dehradun }\end{array}$ & 7 \\
\hline $\begin{array}{l}\text { Rajakiya Prathamik Vidhiyala Bajawal, } \\
\text { Doiwala, Block Dehradun }\end{array}$ & 6 \\
\hline $\begin{array}{l}\text { Ahilyabai Holker Smriti Vidyala, Premnagar } \\
\text { Doiwala, Block Dehradun }\end{array}$ & 8 \\
\hline $\begin{array}{l}\text { Ishaat UI-Uloom Muslim Primary School, } \\
\text { Telepura, Doiwala, Block Dehradun }\end{array}$ & 5 \\
\hline $\begin{array}{l}\text { Rajakiya Prathamik Vidhiyala Jiwan wala } \\
\text { Doiwala, Block Dehradun }\end{array}$ & 6 \\
\hline $\begin{array}{l}\text { Rajakiya Prathamik Vidhiyala Bulawala } \\
\text { Doiwala, Block Dehradun }\end{array}$ & 6 \\
\hline $\begin{array}{l}\text { Rajakiya Prathamik Vidhiyala Telipura } \\
\text { Doiwala, Block Dehradun }\end{array}$ & 6 \\
\hline Total & 50 \\
\hline
\end{tabular}

\begin{tabular}{|c|c|c|}
\hline \multirow[t]{2}{*}{ Sample characteristics } & \multicolumn{2}{|c|}{ Primary school teachers } \\
\hline & Frequency & Percentage \\
\hline \multicolumn{3}{|l|}{ Gender } \\
\hline Male & 3 & 6 \\
\hline Female & 47 & 94 \\
\hline \multicolumn{3}{|l|}{ Age } \\
\hline$<40$ & 25 & 50 \\
\hline$>40$ & 25 & 50 \\
\hline \multicolumn{3}{|l|}{ Educational status } \\
\hline Professional & 39 & 78 \\
\hline Others (BA, B. Ed., MA) & 11 & 22 \\
\hline \multicolumn{3}{|l|}{ Marital status } \\
\hline Married & 30 & 60 \\
\hline Unmarried & 20 & 40 \\
\hline \multicolumn{3}{|l|}{ If married then no of children } \\
\hline One children & 8 & 26.66 \\
\hline More than two children & 22 & 73.33 \\
\hline \multicolumn{3}{|l|}{ Years of experience } \\
\hline $0-15$ & 42 & 84 \\
\hline$>15$ & 8 & 16 \\
\hline \multicolumn{3}{|c|}{$\begin{array}{l}\text { Previous experiences of handling } \\
\text { injured children in school }\end{array}$} \\
\hline Yes & 36 & 72 \\
\hline No & 14 & 28 \\
\hline \multicolumn{3}{|l|}{ Have attended seminar } \\
\hline Yes & 7 & 14 \\
\hline No & 43 & 86 \\
\hline \multicolumn{3}{|l|}{ Information about first aid } \\
\hline Yes & 37 & 74 \\
\hline No & 13 & 26 \\
\hline \multicolumn{3}{|l|}{$\begin{array}{l}\text { If yes than sources of } \\
\text { information }\end{array}$} \\
\hline Through literature & 32 & 64 \\
\hline $\begin{array}{l}\text { Through health personnel, } \\
\text { friends and relatives }\end{array}$ & 18 & 3 \\
\hline
\end{tabular}


magazines, health-related articles and from friends, relatives and health professional.

Table 3 shows that structured educational package in terms of the knowledge was effective and posttest mean knowledge score was significantly higher $(34.76 \pm 4.35)$ than that of pretest mean knowledge score $(27.32 \pm 5.73)$. It shows that through education and training primary school teachers can improve their knowledge.

Table 4 shows that the posttest mean practices score was significantly higher $(18.52 \pm 2.63)$ then the pretest mean practices score $(14.52 \pm 2.39)$. The obtained $t$-value (10.29) was significant at 0.05 level. Hence, above data show that improvement in the practice was not by chance but, it was due to the intervention of structured educational package.

Table 5 shows that there was no association between the pretest knowledge score and selected variables such as gender age, education, marital status, number of children, source of information, previously handling of injured children at school, years of experience, etc.

Table 6 shown that there was a mild correlation $(r=0.47)$ between knowledge score and practice score regarding first aid management before intervention and positive correlation $(r=0.9)$ after the intervention. This shows that when knowledge increases practices also increases.

\section{DISCUSSION}

\section{The findings of the study are discussed as below}

In this study, the knowledge and practices posttest score of primary school teachers were significantly higher compare to pretest knowledge and practice score about first aid management of selected minor injuries such as minor fracture, burn, scald, epistaxis, minor wounds, etc. Similar studies from other parts of world also shows that teachers agreed the all $(90-100 \%)$ that epistaxis, dental injuries and minor abrasion due to sports or playing is common in primary school children. ${ }^{[4,5]}$ Another study also shows that $72-80 \%$ primary school teachers have improved their knowledge and continue practice regarding first aid management for emergency condition in school campus. ${ }^{[6]}$

\section{Effectiveness of structured educational package}

This study indicate that all participants improved their knowledge and practices after the teaching program based on pretest practices mean score $(14.52 \pm 2.39)$ less than posttest practice mean score (18.52 $\pm 2.63)$ and pretest knowledge mean score $(27.32 \pm 5.73)$ less than posttest knowledge mean score $(34.76 \pm 4.35)$. Other similar studies, which has shown that structure educational teaching has improved the knowledge and practice of not only the nursery or primary school teachers, but also mothers of school going children. ${ }^{[7-8]}$

\section{Correlations and co-efficiency between level of knowledge and practices score}

Study shows correlation coefficient relationship between the pretest knowledge and pretest practices had low correlation, the correlation coefficient relationship between the posttest knowledge and posttest practices were highly correlated it means that the correlation is in a positive direction and when knowledge increases practices also increases.

It will be more important that if first aid management for Minor and major injuries can be added to the syllabus of Bachelor of Education course. All primary schools also need to have first aid box in their premises and classrooms. School management can organize or send the teachers for first aid management training.

\section{CONCLUSION}

Most of the time primary school children experience minor injuries such as sprain, strain, minor burn and epistaxis, etc., and they always need first aid care to prevent condition become worse and school teachers are the nearest one's to manage their minor injuries. If school teacher have enough knowledge about first aid management, they may not only help in reducing the complications and absenteeism rate in children, but also save the life of children when needed. Findings showed that in this study structured educational package on first aid management of selected minor injuries was effective. Primary

\begin{tabular}{|c|c|c|c|c|c|}
\hline $\begin{array}{l}\text { Knowledge score of } \\
\text { primary school teachers }\end{array}$ & Maximum possible score & Range & Mean \pm SD & Mean difference & $t$ value \\
\hline Pretest & 42 & $11-36$ & $27.32 \pm 5.73$ & 7.4 & 7.49 \\
\hline Posttest & 42 & $24-39$ & $34.76 \pm 4.35$ & & \\
\hline
\end{tabular}

$P<0.005, \mathrm{SD}=$ Standard deviation

\begin{tabular}{|c|c|c|c|c|c|c|}
\hline $\begin{array}{l}\text { Practices score of primary } \\
\text { school teachers }\end{array}$ & $\begin{array}{l}\text { Maximum possible } \\
\text { score }\end{array}$ & Range & Mean \pm SD & Median & Mean difference & $t$ value \\
\hline Pretest & 23 & $10-19$ & $14.52 \pm 2.39$ & 15 & 4.00 & 10.29 \\
\hline Posttest & 23 & $12-22$ & $18.52 \pm 2.63$ & 19 & & \\
\hline
\end{tabular}

$P<0.005, \mathrm{SD}=$ Standard deviation 


\begin{tabular}{|c|c|c|c|c|c|c|}
\hline Demographic variables & $\begin{array}{c}\text { Above } \\
\text { median }>29\end{array}$ & $\begin{array}{c}\text { Below } \\
\text { median }<29\end{array}$ & $\chi^{2}$ & df & $P$ value & Significance \\
\hline \multicolumn{7}{|l|}{ Gender } \\
\hline Male & 2 & 1 & - & - & 1.00 & NSF \\
\hline Female & 25 & 22 & & & & \\
\hline \multicolumn{7}{|l|}{ Age } \\
\hline Below 40 & 12 & 14 & 1.34 & 1 & 0.24 & NS \\
\hline Above 40 & 15 & 9 & & & & \\
\hline \multicolumn{7}{|l|}{ Education } \\
\hline Professional trained & 19 & 18 & 0.40 & 1 & 0.5 & NS \\
\hline Others & 8 & 5 & & & & \\
\hline \multicolumn{7}{|l|}{ Marital status } \\
\hline Married & 14 & 16 & 1.62 & 1 & 0.20 & NS \\
\hline Unmarried & 13 & 7 & & & & \\
\hline \multicolumn{7}{|l|}{ If married then no of children } \\
\hline One child & 6 & 2 & 2.13 & 1 & 0.14 & NS $*$ \\
\hline More than one child & 8 & 14 & & & & \\
\hline \multicolumn{7}{|l|}{ Years of experiences } \\
\hline $0-15$ years & 25 & 17 & 1.98 & 1 & 0.15 & $N S^{*}$ \\
\hline Above 15 years & 2 & 6 & & & & \\
\hline \multicolumn{7}{|l|}{ Previous handling of injured children } \\
\hline Yes & 21 & 15 & 0.97 & 1 & 0.32 & NS \\
\hline No & 6 & 8 & & & & \\
\hline \multicolumn{7}{|l|}{ Have attended seminar or workshop } \\
\hline Yes & 4 & 3 & - & - & 1.00 & NSF \\
\hline No & 23 & 20 & & & & \\
\hline \multicolumn{7}{|l|}{ Information about first aid } \\
\hline Yes & 18 & 19 & 0.91 & 1 & 0.33 & $\mathrm{NS}^{*}$ \\
\hline No & 9 & 4 & & & & \\
\hline \multicolumn{7}{|l|}{ If yes than source of information } \\
\hline Through literature & 14 & 18 & 3.76 & 1 & 0.05 & NS \\
\hline Through health personnel, relatives and friends & 13 & 5 & & & & \\
\hline
\end{tabular}

"Yates correction test, ${ }^{\text {F }}$ ssure exact test, NS = Not significant

\begin{tabular}{|c|c|c|c|c|}
\hline $\begin{array}{l}\text { Pre- and post-test knowledge and } \\
\text { practice score }\end{array}$ & $\begin{array}{l}\text { Pretest knowledge } \\
\text { score }\end{array}$ & $\begin{array}{c}\text { Pretest practice } \\
\text { score }\end{array}$ & $\begin{array}{l}\text { Post-test knowledge } \\
\text { score }\end{array}$ & $\begin{array}{l}\text { Post-test practice } \\
\text { score }\end{array}$ \\
\hline Pretest knowledge score & - & $r=0.47$ & - & - \\
\hline Pretest practice score & $r=0.47$ & - & - & - \\
\hline Posttest knowledge score & - & - & - & $r=0.9$ \\
\hline Posttest practice score & - & - & $r=0.9$ & - \\
\hline
\end{tabular}

school teachers became more competent to apply their knowledge to practices regarding the first aid management, which they may encounter among the primary school children.

\section{ACKNOWLEDGMENTS}

I would like to express my deepest appreciation to the Dr. Ratna Prakash, Ex-Principal, Himalayan College of Nursing and Dr. Sanchita Pugazhendi, Principal and research consultant of Himalayan College of Nursing for granting the necessary permission and constantly encouraging throughout the research project. In addition, I would like to express my gratitude to Mr. Muthuvenkatchalam S, Assistant professor, $\mathrm{HCN}$ for his statistical guidance, Er. Rupesh Mehrotra for writing this manuscript and the primary school teachers of selected schools for their full cooperation to make this study possible.

\section{ETHICAL CLEARANCE}

This study was approved by the Research and Ethical Committee of HIHT and permission was obtained from Principal of Himalayan College of Nursing. Proper permission was obtained from authorities of Department of Primary Education of Dehradun District and written consent from participants of the study. There was no monetary benefit provided to the participants of the study. 


\section{REFERENCES}

1. Gupta LC. Manual of FirstAid. $1^{\text {st }}$ ed. New Delhi: Jypee publisher; 2004. p. 110-6.

2. Gulani KK. Community Health Nursing Principles and Practices. $1^{\text {st }}$ ed. New Delhi: Jypee publisher; 2005. p. 285-444.

3. Basvanthappa BT. Community Health Nursing. $2^{\text {nd }}$ ed. New Delhi: Jypee publisher; 2009. p. 536-7.

4. Wilson CC. First aid cabinet of a school nurse, her standing orders for first aid, and her school nursing procedure. Am J Public Health Nations Health 1930;20:147-54.

5. Kelm J, Ahlhelm F, Pape D, Pitsch W, Engel C. School sports accidents: analysis of causes, modes, and frequencies. J Pediatr Orthop 2001;21:165-8.

6. Salwa A. Ali, Amany R. Abu-Elseoud, Soheir M. Heybah, Azhar A. Mohame. Implementation of an education training programme. Zigzag J Occup Health Saf 2010;3:21.
7. Sonavane RS. Knowledge attitude \& practice of first aid among women in a rural area. Bangalore: Community Dept. of St John Medical College; 2008. p. 1-143.

8. Maloti DK. The study on assess the effectiveness of teaching programme on knowledge regarding first aid in selected condition among primary school teacher working in primary schools. Bangalore: Community Medicine Dept. M.S. Ramaiah Institute of Nursing Education and Research; 2006. p. 1-130

How to cite this article: Masih S, Sharma RK, KumarA. Knowledge and practice of primary school teachers about first aid management of selected minor injuries among children. Int J Med Public Health 2014;4:458-62.

Source of Support: Nil, Conflict of Interest: None declared. 